\title{
Ensemble Classifier untuk Klasifikasi Kanker Payudara
}

\author{
Khadijah $^{1}$, Retno Kusumaningrum ${ }^{2}$ \\ Departemen Ilmu Komputer/ Informatika, Fakultas Sains dan Matematika, Universitas Diponegoro, ${ }^{1,2}$ \\ khadijah@live.undip.ac.id ${ }^{1}$,retno@live.undip.ac.id ${ }^{2}$
}

\begin{tabular}{l}
\hline Article Info \\
\hline History: \\
Dikirim 01 Agustus 2019 \\
Direvisi 15 Agustus 2019 \\
Diterima 22 Agustus 2019 \\
\hline
\end{tabular}

\section{Kata Kunci :}

Klasifikasi

Ensemble Classifier

Kanker Payudara

ELM

SVM

$\mathrm{KNN}$

\begin{abstract}
Abstrak
Kanker payudara merupakan jenis kanker yang paling banyak diderita oleh kaum wanita di Indonesia. Penyakit tersebut dapat berakibat pada kematian jika terlambat ditangani. Oleh karena itu, deteksi dini kanker payudara merupakan langkah awal untuk menyelamatkan nyawa pasien. Pada penelitian ini telah dilakukan klasifikasi kanker payudara berdasarkan data anthopometric serta data dari hasil tes darah rutin menggunakan single classifier (ELM, SVM dan kNN) dan ensemble classifier yang menggabungkan ketiga algoritma tersebut dengan penentuan kelas majority voting. Pembagian data dilakukan dengan three way data split. Hasil eksperimen menunjukkan bahwa saat menggunakan keseluruhan fitur penggunaan ensemble classifier lebih baik daripada single classifier dalam hal akurasi maupun G-mean. Namun, saat menggunakan 4 fitur terbaik (resistin, glucose, age, dan BMI) penggunaan ensemble classifier sedikit lebih baik dalam hal G-mean, akan tetapi lebih rendah dalam hal akurasi. Hal ini disebabkan minimnya diversity di antara classifier sehingga saat digabungkan tidak mampu memperbaiki hasil.
\end{abstract}

(C) This work is licensed under a Creative Commons AttributionShareAlike 4.0 International License.

\section{Koresponden:}

Khadijah

Departemen Ilmu Komputer/ Informatika, Fakultas Sains dan Matematika

Universitas Diponegoro,

Jl. Prof. Soedarto, S.H. Tembalang Semarang, Indonesia, 50275

Email : khadijah@live.undip.ac.id

\section{PENDAHULUAN}

Kanker adalah penyakit yang diakibatkan oleh sel-sel abnormal yang tumbuh dan menyebar secara tidak terkendali [1]. Berdasarkan data Globocan Tahun 2018 Indonesia menempati peringkat 8 di Asia Tenggara dan 23 di Asia dalam hal jumlah kejadian kanker. Khusus untuk kaum wanita di Indonesia, kanker payudara merupakan jenis kanker yang banyak diderita dengan angka kejadian 42,1 per 100.000 penduduk dan angka kematian rata-rata 17 per 100.000 penduduk [2]. Penderita kanker memiliki kesempatan lebih besar untuk sembuh atau bertahan hidup jika segera mendapatkan treatment yang tepat [1]. Oleh karena itu, deteksi dini penyakit kanker sangat perlu dilakukan agar pasien dapat segera menjalani treatment seawal mungkin.

Deteksi kanker dapat dilakukan melalui beberapa cara, misalnya berdasarkan struktur morfologis atau kelainan pada eskpresi gen. Akan tetapi, struktur morfologis antara jenis kanker yang berbeda memiliki kemiripan yang cukup tinggi, sehingga deteksi berdasarkan hal tersebut 
sulit untuk dilakukan [3]. Sedangkan eksperimen microarray untuk mendapatkan nilai ekspresi gen membutuhkan biaya yang cukup besar [4]. Oleh karena itu, [5] mencoba mencari kandidat biomarker yang dapat digunakan untuk deteksi kanker payudara dengan biaya yang lebih murah berdasarkan data anthopometric dan hasil tes darah rutin. Penelitian tersebut lebih terfokus pada pemilihan fitur atau biomarker yang representatif untuk diagnosis kanker payudara. Penelitian tersebut juga mencoba beberapa algoritma untuk membangun classifier berdasarkan fitur yang dipilih, yaitu Support Vector Machine (SVM), Logistic Regression dan Random Forest. Hasil eksperimen menunjukkan bahwa SVM memberikan performa terbaik pada berbagai kombinasi fitur yang digunakan.

Di samping algoritma SVM, algoritma klasifikasi lain yang juga memberikan hasil yang baik dalam permasalahan klasifikasi kanker adalah Extreme Learning Machine (ELM) [6][7] dan kNearest Neighbor $(\mathrm{kNN})[8][9]$. ELM adalah algoritma pembelajaran untuk single hidden layer feedforward network yang lebih baik dari algoritma gradient descent learning karena memerlukan waktu pelatihan yang lebih singkat, jumlah parameter pelatihan yang lebih sedikit dan kemampuan generalisasi yang lebih baik [10][11]. kNN adalah lazy learner yang mengklasifikasikan data berdasarkan label kelas mayoritas dari sejumlah tetangga terdekatnya [12]. Meskipun konsep algoritma kNN sederhana, akan tetapi algoritma ini mampu mencapai akurasi $98,70 \%$ pada klasikasi Wisconsin Breast Cancer Database [8] dan 96,33\% pada klasifikasi gastric cancer [9].

Beberapa penelitian mencoba meningkatkan hasil klasifikasi dengan menerapkan ensemble method. Ensemble method melatih sejumlah classifier atau base learner dan kemudian mengkombinasikan hasilnya. Base learner yang digunakan dapat berupa algoritma klasifikasi apapun, seperti decision tree, Naïve Bayes classifier, jaringan syaraf tiruan, SVM dan sebagainya [13]. Hasil eksperimen menunjukkan bahwa penggunaan ensemble classifier memberikan performa yang lebih baik daripada single classifier [14][15]. Hal ini disebabakan, sebuah classifier atau base learner umumnya memiliki letak kesalahan (error) pada instance data tertentu. Classifier yang berbeda juga dapat memiliki letak kesalahan pada instance data yang berbeda. Hal itu disebut dengan istilah diversity di antara classifier. Oleh karena itu, ensemble method menggabungkan sejumlah classifier yang berbeda dengan tujuan agar letak kesalahan pada sebuah classifier dapat diperbaiki oleh classifier lainnya, sehingga pada akhirnya didapat error yang lebih kecil daripada saat menggunakan sebuah classifier saja. Akan tetapi supaya tujuan tersebut dapat dicapai, harus terdapat diversity pada sejumlah classifier yang digunakan [16]. Salah satu cara untuk mencapai diversity adalah dengan menggunakan algoritma klasifikasi yang berbeda [14]. Oleh karena itu, pada penelitian ini digunakan ensemble classifier yang menggabungkan ketiga algoritma yang berasal dari konsep yang berbeda untuk mencapai diversity, yaitu SVM (statistical classifier), ELM (artificial neural network) dan kNN (lazy learner). Selanjutnya, dapat dibandingkan hasil yang dicapai oleh ensemble classifier dan single classifier.

\section{METODE PENELITIAN}

Gambaran umum proses pada penelitian ini dapat dilihat pada Gambar 1. Terdapat tiga proses utama, yaitu normalisasi dan pemilihan fitur, klasifikasi dan evaluasi. Detail untuk masingmasing proses tersebut dijelaskan pada sub-bab berikutnya. Sebelumnya, dijelaskan terlebih dahulu mengenai dataset dan pembagian data yang digunakan.

\subsection{Dataset}

Dataset yang digunakan pada penelitian ini adalah dataset Breast Cancer Coimbra yang diunduh dari UCI Machine Learning Repository (https://archive.ics.uci.edu/ml/datasets/Breast+Cancer+Coimbra). Dataset tersebut dikumpulkan dari Gynaecology Department pada University Hospital Centre of Coimbra (CHUC) selama tahun 2009-2013 yang terdiri atas 52 pasien normal (negatif) dan 64 pasien kanker payudara (positif). Setiap record data terdiri atas 10 atribut, terbagi atas 9 atribut fitur bertipe numerik dan satu atribut keputusan bertipe kategori yang menyatakan positif/ negatif kanker. Atribut fitur terdiri atas data anthopometric (usia dan BMI) serta data yang didapat dari hasil tes darah rutin (glucose, insulin, HOMA, leptin, adiponectin, resistin, MCP-1) seperti pada Tabel 1 [5]. 


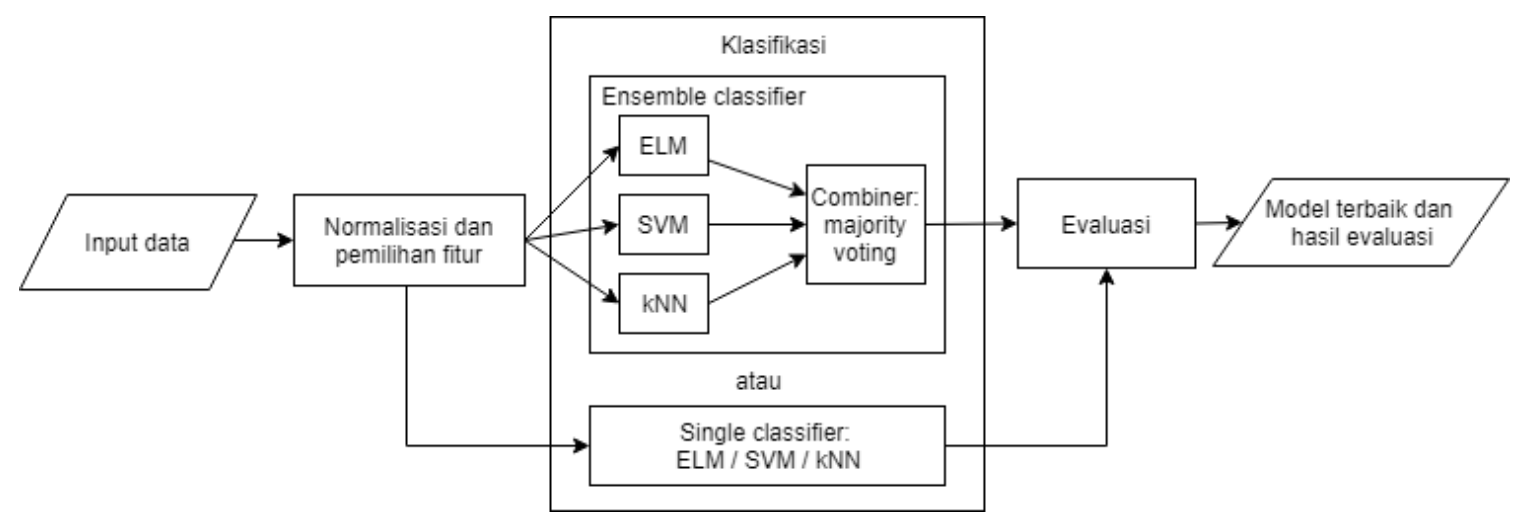

Gambar 1. Gambaran Umum Proses Penelitian

Tabel 1. Deskripsi Atribut pada Dataset [5]

\begin{tabular}{llrr}
\hline \multicolumn{1}{c}{ Fitur } & \multicolumn{1}{c}{ Keterangan } & Nilai Minimal & Nilai Maksimal \\
\hline Usia & Usia pasien & 24 & 89 \\
\hline BMI & Body Mass Index & 18,37 & 38,579 \\
\hline Glucose & Kadar glukosa dalam serum & 60 & 201 \\
\hline Insulin & Kadar insulin dalam serum & 2,432 & 58,46 \\
\hline HOMA & $\begin{array}{l}\text { Nilai indeks Homeostasis Model } \\
\text { Assessment }\end{array}$ & 0,467 & 25,050 \\
\hline Leptin & Kadar leptin dalam serum & 4,311 & 90,280 \\
\hline Adiponectin & Kadar adiponectin dalam serum & 1,656 & 38,040 \\
\hline Resistin & Kadar resistin dalam serum & 3,21 & 82,1 \\
\hline MCP-1 & Kadar Monocyte Chemoattractant & & \\
& Protein 1 dalam serum & 45,843 & 1698,440 \\
\hline Kategori & Kategori pasien & $1=$ negatif & $2=$ positif \\
\hline
\end{tabular}

\subsection{Pembagian Data}

Klasifikasi terdiri atas dua proses utama, yaitu pelatihan dan pengujian. Pelatihan bertujuan untuk membangun model atau classifier, selanjutnya pengujian bertujuan untuk mengevaluasi classifier tersebut. Agar hasil pengujian minimal dari bias, maka subset data yang dipakai untuk pelatihan dan pengujian harus berbeda. Oleh karena itu, perlu dilakukan pembagian dataset untuk memisahkan subset data untuk proses pelatihan dan pengujian.

Pembagian data dilakukan dengan three-way data split, yaitu dataset dibagi menjadi data latih, data validasi dan data uji. Pertama, dataset dibagi menjadi data latih (93 sampel) dan data uji (23 sampel) menggunakan random subsampling dengan perbandingan yang seimbang antar kelas positif dan negatif dan diulang sebanyak sepuluh kali. Selanjutnya, data latih dibagi lagi menjadi data latih yang sesungguhnya dan data validasi menggunakan stratified $\mathrm{k}$-fold cross validation $(k=5)$. Data validasi digunakan untuk mengevaluasi hasil pelatihan dalam rangka memilih kombinasi parameter terbaik untuk pelatihan, sedangkan data uji digunakan untuk mengevaluasi classifier akhir yang telah dilatih menggunakan kombinasi parameter terbaik. Pembagian data dengan cara seperti ini dilakukan agar data latih dan data uji benar-benar independen, yang bertujuan untuk meminimalkan bias pada hasil akhir yang diperoleh.

\subsection{Normalisasi dan Pemilihan Fitur}

Normalisasi bertujuan untuk menyeragamkan range data pada setiap jenis fitur, sehingga mencegah overweighting pada fitur yang memiliki range data besar terhadap atribut yang memiliki range data kecil. Normalisasi yang digunakan pada penelitian ini adalah min-max normalization dengan range $[-1,1]$, artinya range nilai setiap fitur diskalakan sehingga nilai minimumnya menjadi -1 dan nilai maksimumnya menjadi 1 [12]. Sedangkan untuk pemilihan fitur akan dicoba dengan 
dua cara, yaitu menggunakan keseluruhan fitur dan menggunakan empat fitur terbaik pada penelitian sebelumnya (resistin, glucose, age dan BMI) [5].

\subsection{Klasifikasi}

Pada penelitian ini klasifikasi dilakukan dengan ensemble classifier dan single classifier. Single classifier yang digunakan meliputi ELM, SVM dan kNN, sedangkan ensemble classifier menggabungkan ketiga algoritma tersebut.

\subsubsection{Ensemble Method}

Ensemble method melatih sejumlah base learner untuk menyelesaikan suatu permasalahan dan kemudian mengkombinasikan hasilnya. Ensemble method dapat dibangun dengan menggunakan satu jenis algoritma klasifikasi namun dilatih dengan subset data yang berbeda (homogeneous ensembles), atau menggunakan algoritma klasifikasi yang berbeda (heterogenous ensembles) [13]. Karena jumlah dataset yang terbatas, penelitian ini menggunakan dataset yang sama untuk melatih beberapa classifier yang berbeda, yaitu ELM, SVM dan kNN. Selanjutnya, output dari masingmasing classifier atau learner dikombinasikan. Aturan kombinasi yang digunakan pada penelitian ini adalah majority voting karena aturan tersebut sederhana dan banyak digunakan. Pada majority voting, setiap learner akan memberikan output berupa sebuah label kelas untuk sebuah masukan. Selanjutnya, label kelas final adalah label kelas yang memiliki jumlah vote lebih dari setengah jumlah learner yang digunakan dalam ensemble method. Jika tidak ada label kelas yang memenuhi kondisi tersebut, maka ensemble method akan mengeluarkan opsi rejection atau dengan kata lain tidak ada prediksi label yang dihasilkan [13].

\subsubsection{Extreme Learning Machine}

Extreme learning machine (ELM) pertama kali dikembangkan pada tahun 2004 [10] dan disempurnakan menjadi ELM untuk generalized single hidden layer feedforward neural network (SLFN) [11]. Contoh arsitektur jaringan syaraf tiruan dengan satu node output yang dapat dilatih dengan ELM ditunjukkan pada Gambar 2. Nilai $\mathbf{a}_{j}$ dan $b_{j}$ adalah parameter pada hidden node ke- $j$, sedangkan $\boldsymbol{\beta}=\left[\beta_{1}, \ldots, \beta_{L}\right]^{T}$ adalah vektor bobot dari hidden node ke sebuah output node. Fungsi output untuk sebuah output node pada ELM dapat dilihat pada persamaan (1) dengan $\mathbf{x}=$ $\left[x_{1}, \ldots, x_{d}\right]^{T} \in \mathbf{R}^{d}$ adalah vektor input dan $\mathbf{h}(\mathbf{x})=\left[h_{1}(\mathbf{x}), \ldots, h_{L}(\mathbf{x})\right]^{T}$ adalah vektor output dari hidden layer untuk sebuah masukan $\mathbf{x}$. Pada penelitian ini $\mathbf{x}$ adalah feature set yang telah dinormalisasi. Nilai keluaran pada hidden node ke- $j$, yaitu $h_{j}(\mathbf{x})$ dihitung menggunakan fungsi aktivasi $G\left(\mathbf{a}_{j}, b_{j}, \mathbf{x}\right)$. Fungsi aktivasi yang digunakan dapat berupa fungsi sigmoid atau hard-limit pada feedforward neural network, serta fungsi Gaussian atau multiquadric pada RBF network. Selanjutnya, label kelas menggunakan fungsi $\operatorname{sign}(f(\mathbf{x}))$. Jika digunakan multioutput node, maka jumlah node output diset sesuai jumlah kelas, dan label dari suatu masukan ditentukan dari indeks node output yang memberikan nilai tertinggi [11].

$$
\begin{gathered}
f(\mathbf{x})=\sum_{j=1}^{L} \beta_{j} h_{j}(\mathbf{x})=\mathbf{h}(\mathbf{x}) \boldsymbol{\beta} \\
\mathbf{H}=\left[\begin{array}{c}
\mathbf{h}\left(\mathbf{x}_{1}\right) \\
\vdots \\
\mathbf{h}\left(\mathbf{x}_{N}\right)
\end{array}\right]=\left[\begin{array}{ccc}
h_{1}\left(\mathbf{x}_{1}\right) & \ldots & h_{L}\left(\mathbf{x}_{1}\right) \\
\vdots & \vdots & \vdots \\
h_{1}\left(\mathbf{x}_{N}\right) & \ldots & h_{L}\left(\mathbf{x}_{N}\right)
\end{array}\right]_{N \times L} \\
\boldsymbol{\beta}=\mathbf{H}^{\mathrm{T}}\left(\frac{\mathbf{I}}{C}+\mathbf{H H}^{\mathbf{T}}\right)^{-1} \mathbf{T}
\end{gathered}
$$




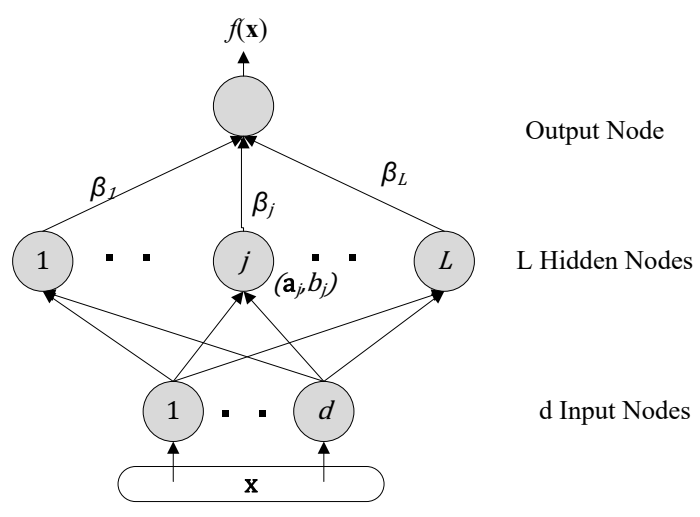

Gambar 2. Contoh Arsitektur Jaringan Syaraf Tiruan untuk ELM [17]

Algoritma pelatihan ELM menggunakan $N$ pasangan input-output $\left(x_{i}, t_{i}\right)_{i=1}^{N}$ dengan $x_{i}=$ $\left[x_{i 1}, x_{i 2}, \ldots, x_{i d}\right]^{T} \in R^{d}$ adalah vektor input data ke-i dan $t_{i}=\left[t_{i 1}, t_{i 2}, \ldots, t_{i m}\right]^{T} \in R^{m}$ adalah nilai target data ke- $i$. Parameter pada hidden node $\left(a_{j}, b_{j}\right)_{j=1}^{L}$ di-generate secara random, sedangkan bobot output $\beta$ dihitung dengan persamaan (2) dengan $H$ adalah hidden layer output matrix seperti persamaan (3) dan $T=\left[\begin{array}{c}t_{1}^{T} \\ \vdots \\ t_{N}^{T}\end{array}\right]_{N \times m} \quad$ adalah matriks target untuk data latih ke $1 . . N, I$ adalah matriks identitas dan $C$ adalah parameter regularisasi [11].

\subsubsection{Support Vector Machine}

Support Vector Machine (SVM) adalah algoritma untuk klasifikasi biner yang memisahkan data pada dua kelas berbeda dengan mencari maximum marginal hyperplane $(\mathrm{MMH})$, yaitu optimal hyperplane dengan margin terbesar. Sebagai contoh Gambar 3 menunjukkan pemetaan data $\left(\mathbf{x}_{i}, y_{i}\right)$ dari dua kelas yang berbeda yang terdiri atas dua atribut, yaitu $A_{1}$ dan $A_{2}$. Gambar 3(b) lebih baik dari Gambar 3(a) sebab garis pemisahnya memiliki margin yang lebih besar.

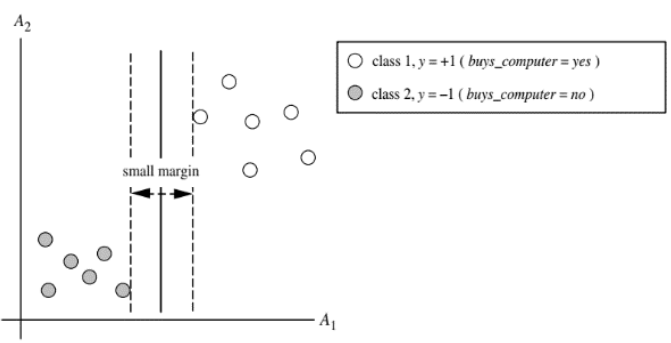

(a)

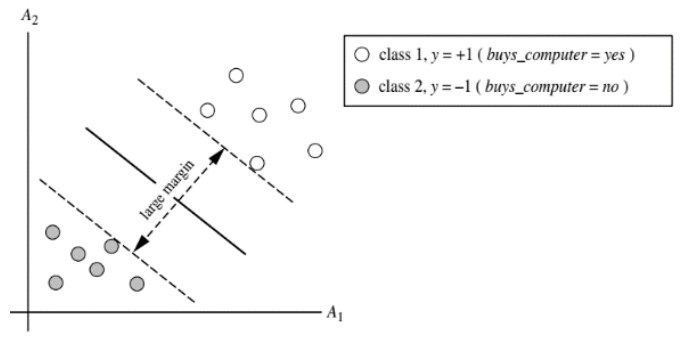

(b)

Gambar 3. Contoh Pemetaan Data 2 Kelas (a) small margin (b) large margin [12]

Hyperplane yang mendefinisikan kedua sisi margin dapat dituliskan dengan $H_{1}$ dan $H_{2}$ seperti persamaan (4) dan (5) dengan $\mathrm{W}=\left\{\mathrm{w}_{0}, \mathrm{w}_{1}, \mathrm{w}_{2}\right\}$ adalah vektor bobot. Data latih yang berada di $H_{1}$ atau $H_{2}$ disebut hyperplane sebagai support vector. Algoritma pelatihan SVM bertujuan untuk menemukan MMH dan support vector.

$$
\begin{gathered}
H_{1}: w_{0}+w_{1} x_{1}+w_{2} x_{2} \geq 1 \text { for } y_{i}=+1 \\
H_{2}: w_{0}+w_{1} x_{1}+w_{2} x_{2} \leq-1 \text { for } y_{i}=-1
\end{gathered}
$$

Selanjutnya, sebuah data baru $\mathbf{x}_{\text {test }}$ dapat diklasifikasikan menggunakan persamaan (6) dengan $\mathbf{x}_{\mathrm{i}}$ adalah support vector ke- $i, y_{\mathrm{i}}$ adalah kelas data untuk support vector $\mathbf{x}_{\mathrm{i}}$ serta $\alpha_{\mathrm{i}}$ dan $\mathrm{b}_{0}$ 
adalah parameter numerik yang didapat dari algoritma pelatihan SVM. Data $\mathbf{x}_{\text {test }}$ diklasifikasikan ke kelas +1 jika $d\left(\mathbf{x}_{\text {test }}\right)$ bernilai positif atau ke kelas -1 jika $d\left(\mathbf{x}_{\text {test }}\right)$ bernilai negatif.

$$
d\left(\mathbf{x}_{\text {test }}\right)=\sum_{i=1}^{l} y_{i} \alpha_{i} \mathbf{x}_{i} \mathbf{x}_{\text {test }}+b_{0}
$$

Untuk kasus non-linearly separable data, maka data akan dipetakan terlebih dahulu ke dimensi yang lebih tinggi menggunakan non-linear mapping. Nonlinear mapping $\phi\left(\mathrm{X}_{\mathrm{i}}\right)$ dapat diterapkan menggunakan fungsi kernel seperti persamaan (7). Beberapa pilihan fungsi kernel yang dapat digunakan antara lain linear, Gaussian atau radial basis function.

$$
K\left(\mathbf{x}_{i}, \mathbf{x}_{j}\right)=\phi\left(\mathbf{x}_{i}\right) \cdot \phi\left(\mathbf{x}_{i}\right)
$$

\subsection{4. $k$-Nearest Neighbor}

Metode $k$-nearest neighbor ( $k$-NN) adalah metode klasifikasi yang termasuk lazy learner sebab metode ini tidak memerlukan proses pelatihan untuk membangun sebuah model classifier. Pada metode ini, setiap data atau tuple $\mathbf{x}$ merepresentasikan sebuah titik pada ruang berdimensi $d$. Selanjutnya, $k$-NN melakukan prediksi kelas dari sebuah test tuple (titik) dengan mencari $k$ tuple (titik) terdekat dengan test tuple tersebut pada ruang berdimensi $d$. Untuk menentukan titik-titik terdekat dibutuhkan ukuran kedekatan dan ukuran kedekatan yang banyak digunakan adalah jarak Euclidean. [12]

Langkah-langkah dalam algoritma $k$-NN untuk memprediksi label kelas dari sebuah test tuple $\mathbf{x}_{\text {test }}$ adalah sebagai berikut [12]:

1. Menghitung jarak antara test tuple $\mathbf{x}_{\text {test }}$ dengan semua tuple yang ada di data latih $\left(\mathbf{x}_{i}, t_{i}\right)_{i=1}^{N}$ dengan dengan $\mathbf{x}_{i}$ adalah vektor input dan $t_{i}$ adalah nilai target data ke- $i$

2. Menemukan $k$ tetangga terdekat, yaitu $k$ tuple di data latih yang memiliki jarak terdekat dengan dengan test tuple $\mathbf{x}_{\text {test }}$.

3. Menentukan label kelas dari test tuple $\mathbf{x}_{\text {test }}$ dengan cara:

a. Jika $k=1$, maka test tuple $\mathbf{x}_{\text {test }}$ diklasifikasikan ke kelas data dari tuple tetangga.

b. Jika $k>1$, maka test tuple $\mathbf{x}_{\text {test }}$ diklasifikasikan berdasarkan kelas terbanyak dari tuple tetangga (majority voting).

\subsection{Metrik Evaluasi}

Permasalahan yang diselesaikan dalam penelitian ini adalah klasifikasi biner. Dengan demikian, model atau classifier yang dihasilkan dievaluasi menggunakan metrik berupa akurasi, sensitivity dan specificity. Akurasi menyatakan perbandingan antara jumlah data yang diklasifikasikan dengan benar oleh classifier dengan jumlah data keseluruhan. Sensitivity menyatakan perbandingan antara jumlah data di kelas positif yang diklasifikasikan dengan benar oleh classifier ke kelas positif (true positive) dengan jumlah data yang seharusnya di kelas positif. Specificity menyatakan perbandingan antara jumlah data di kelas negatif yang diklasifikasikan oleh classifier ke kelas negatif (true negative) dengan jumlah data yang seharusnya di kelas negatif [12]. Di samping itu, untuk mengetahui kemampuan rata-rata pengenalan classifier di kelas positif maupun negatif, dihitung pula nilai G-mean. G-mean merupakan merupakan hasil kali nilai senisitivity dan specificity yang nilainya tidak terpengaruh saat perbandingan jumlah data di kelas positif dan negatif tidak sama [18].

\section{HASIL DAN PEMBAHASAN}

Pada eksperimen ini dilakukan dua skenario. Skenario pertama menggunakan keseluruhan fitur pada dataset sebagai masukan untuk klasifikasi, sedangkan skenari kedua hanya menggunakan 4 fitur terbaik yang telah dipilih pada penelitian sebelumnya [5]. Pada masing-masing skenario dilakukan klasifikasi menggunakan classifier tunggal untuk mendapatkan kombinasi parameter terbaik pada masing-masing classifier. Selanjutnya, masing-masing classifier tersebut digabungkan membentuk ensemble classifier. 
Pada classifier ELM terdapat 2 parameter yang diuji coba untuk mendapatkan hasil yang optimal, yaitu fungsi aktivasi pada hidden node dan nilai parameter regularisasi. Fungsi aktivasi hidden node yang dicoba adalah sigmoid, hard-limit, Gaussian dan multiquadric. Nilai parameter regularisasi yang dicoba adalah dalam rentang $\left\{2^{-25}, 2^{-24}, \ldots, 2^{24}, 2^{25}\right\}$ dan jumlah hidden node $(L)$ yang digunakan adalah 1000 sesuai nilai yang digunakan pada penelitian [11]. Pada classifier SVM fungsi kernel yang digunakan diuji coba dengan beberapa kemungkinan, yaitu fungsi Linear, Gaussian, dan RBF. Pada classifier kNN ukuran kedekatan yang digunakan adalah jarak Euclidean dan jumlah tetangga $(k)$ yang digunakan diuji coba dengan beberapa nilai, yaitu 5, 7, 11 dan 11 .

\subsection{Skenario 1}

Hasil eksperimen skenario pertama yang menggunakan keseluruhan fitur pada dataset, dapat dilihat pada Tabel 2, 3 dan 4 secara berurutan untuk classifier ELM, SVM, dan kNN. Saat menggunakan classifier ELM, hanya ditampilkan nilai $C$ yang memberikan hasil terbaik. Eksperimen tersebut dilakukan dengan 5-fold cross validation hanya pada 93 sampel data dan bertujuan untuk mendapatkan kombinasi parameter terbaik pada masing-masing classifier. Pada Tabel 2 terlihat bahwa hasil terbaik didapat saat menggunakan fungsi aktivasi sigmoid. Akurasi terbaik pada classifier SVM didapat saat menggunakan fungsi kernel Gaussian atau RBF. Hal ini dapat disebabkan karena data yang bersifat non-linearly separable, sehingga saat menggunakan fungsi kernel linear akurasinya menjadi lebih rendah. Saat menggunakan classifier kNN, terlihat bahwa semakin banyak jumlah tetangga yang digunakan akurasi maupun G-mean semakin tinggi. Hal ini dapat disebabkan karena data dari kelas yang berbeda menempati ruang yang cukup berdekatan, akibatnya semakin banyak tetangga yang diperlukan sebagai dasar penentuan label kelas untuk suatu data agar didapat hasil prediksi lebih tepat.

Tabel 2. Rata-Rata Hasil 5-Cross Validation pada ELM Menggunakan 9 Fitur

\begin{tabular}{ccrrrr}
\hline Fungsi Aktivasi & C & Akurasi & Sensitivity & Specificity & \multicolumn{1}{c}{ G-mean } \\
\hline Sigmoid & $2^{0}$ & $81.50 \%$ & $81.48 \%$ & $81.07 \%$ & $81.28 \%$ \\
\hline Hard limit & $2^{17}$ & $77.82 \%$ & $77.78 \%$ & $77.38 \%$ & $77.58 \%$ \\
\hline Gaussian & $2^{1}$ & $79.39 \%$ & $80.74 \%$ & $77.14 \%$ & $78.92 \%$ \\
\hline Multiquadric & $2^{0}$ & $80.12 \%$ & $82.22 \%$ & $77.14 \%$ & $79.64 \%$ \\
\hline
\end{tabular}

Tabel 3. Rata-Rata Hasil 5-Cross Validation pada SVM Menggunakan 9 Fitur

\begin{tabular}{crrrr}
\hline Fungsi Kernel & Akurasi & Sensitivity & Specificity & G-mean \\
& & & & \\
\hline Gaussian & $74.12 \%$ & $88.89 \%$ & $55.36 \%$ & $70.15 \%$ \\
\hline RBF & $74.12 \%$ & $88.89 \%$ & $55.36 \%$ & $70.15 \%$ \\
\hline Linear & $72.75 \%$ & $74.07 \%$ & $70.83 \%$ & $72.44 \%$ \\
\hline
\end{tabular}

Tabel 4. Rata-Rata Hasil 5-Cross Validation pada kNN Menggunakan 9 Fitur

\begin{tabular}{crrrr}
\hline Jumlah Tetangga $(\boldsymbol{k})$ & Akurasi & Sensitivity & Specificity & G-mean \\
\hline 5 & $70.44 \%$ & $68.89 \%$ & $71.79 \%$ & $70.32 \%$ \\
\hline 7 & $72.94 \%$ & $75.56 \%$ & $69.29 \%$ & $72.35 \%$ \\
\hline 9 & $76.62 \%$ & $75.56 \%$ & $77.50 \%$ & $76.52 \%$ \\
\hline $\mathbf{1 1}$ & $79.12 \%$ & $77.78 \%$ & $80.36 \%$ & $79.06 \%$ \\
\hline
\end{tabular}

Setelah mendapatkan kombinasi parameter terbaik, classifier dibangun menggunakan 93 data latih dan kombinasi parameter tersebut, kemudian diuji menggunakan 23 data uji. Rata-rata hasil pengujian dari 10 eksperimen pada masing-masing classifier dan ensemble classifier ditunjukkan pada Tabel 5. Terlihat bahwa akurasi yang didapat oleh single classifier ELM, SVM dan kNN hampir sama atau tidak jauh berbeda, akan tetapi jika dilihat dari G-mean, SVM memberikan hasil yang terendah (terlihat dari nilai sensitivity dan specificity yang tidak seimbang). Namun, ketika masing-masing classifier tersebut digabung menjadi ensemble classifier akurasi dan 
G-mean yang didapat lebih tinggi daripada hasil dari masing-masing classifier. Hal ini menunjukkan bahwa penggunaan ensemble classifier mampu meningkatkan performa klasifikasi dalam hal akurasi maupun G-mean.

Tabel 5. Rata-Rata Hasil Pengujian Menggunakan 9 Fitur

\begin{tabular}{crrrr}
\hline Classifier & Akurasi & Sensitivity & Specificity & \multicolumn{1}{c}{ G-mean } \\
\hline ELM & $70.43 \%$ & $73.08 \%$ & $67.00 \%$ & $69.29 \%$ \\
\hline SVM & $69.13 \%$ & $90.00 \%$ & $42.00 \%$ & $60.32 \%$ \\
\hline kNN & $70.87 \%$ & $72.31 \%$ & $69.00 \%$ & $69.82 \%$ \\
\hline Ensemble & $72.17 \%$ & $78.46 \%$ & $64.00 \%$ & $70.35 \%$ \\
\hline
\end{tabular}

\subsection{Skenario 2}

Pada skenario kedua masukan ke classifier hanya menggunakan 4 fitur terbaik yang dipilih pada penelitian sebelumnya [5], yaitu Glucose, Resistin, BMI dan Age. Hasil eksperimen ditunjukkan pada Tabel 6, 7, dan 8 secara berurutan untuk classifier ELM, SVM, dan kNN. Hasil yang didapat mengalami peningkatan dibanding saat menggunakan keseluruhan fitur, baik pada algoritma ELM, SVM maupun kNN. Pada hasil tersebut juga terlihat bahwa kombinasi parameter terbaik untuk classifier ELM dan kNN berbeda dengan saat menggunakan keseluruhan fitur, kecuali pada SVM. Hal ini menunjukkan bahwa saat menggunakan 4 fitur pemetaan data menjadi berbeda dengan saat menggunakan keseluruhan fitur, akan tetapi karakteristik non-linearly separable tetap ada, sehingga saat menggunakan SVM, fungsi kernel Gaussian atau RBF memberikan hasil yang lebih baik daripada fungsi kernel linear. Pada classifier ELM hasil terbaik didapat saat menggunakan fungsi aktivasi multiquadric. Pada classifier $\mathrm{kNN}$ terlihat bahwa tidak terdapat pola yang teratur antara pertambahan jumlah tetangga yang digunakan dengan peningkatan atau penurunan hasil yang didapat. Hasil terbaik didapat saat menggunakan $k=7$.

Tabel 6. Rata-Rata Hasil 5-Cross Validation pada ELM Menggunakan 4 Fitur

\begin{tabular}{ccrrrr}
\hline Fungsi Aktivasi & C & Akurasi & Sensitivity & Specificity & \multicolumn{1}{c}{ G-mean } \\
\hline Sigmoid & $2^{7}$ & $85.17 \%$ & $90.37 \%$ & $78.57 \%$ & $84.26 \%$ \\
\hline Hard limit & $2^{-1}$ & $83.55 \%$ & $83.70 \%$ & $83.10 \%$ & $83.40 \%$ \\
\hline Gaussian & $2^{-3}$ & $87.67 \%$ & $91.11 \%$ & $82.98 \%$ & $86.95 \%$ \\
\hline Multiquadric & $2^{-3}$ & $88.06 \%$ & $88.89 \%$ & $86.67 \%$ & $87.77 \%$ \\
\hline
\end{tabular}

Tabel 7. Rata-Rata Hasil 5-Cross Validation pada SVM Menggunakan 4 Fitur

\begin{tabular}{crrrr}
\hline Fungsi Kernel & Akurasi & Sensitivity & Specificity & G-mean \\
\hline Gaussian & $82.72 \%$ & $91.11 \%$ & $72.14 \%$ & $81.07 \%$ \\
\hline RBF & $82.72 \%$ & $91.11 \%$ & $72.14 \%$ & $81.07 \%$ \\
\hline Linear & $75.37 \%$ & $68.89 \%$ & $82.86 \%$ & $75.55 \%$ \\
\hline
\end{tabular}

Tabel 8. Rata-Rata Hasil 5-Cross Validation pada kNN Menggunakan 4 Fitur

\begin{tabular}{crrrr}
\hline Jumlah Tetangga $(\boldsymbol{k})$ & Akurasi & Sensitivity & Specificity & G-mean \\
\hline 5 & $80.22 \%$ & $84.44 \%$ & $74.29 \%$ & $79.20 \%$ \\
\hline 7 & $81.40 \%$ & $88.89 \%$ & $71.43 \%$ & $79.68 \%$ \\
\hline 9 & $77.65 \%$ & $80.00 \%$ & $74.29 \%$ & $77.09 \%$ \\
\hline 11 & $78.97 \%$ & $84.44 \%$ & $71.79 \%$ & $77.86 \%$ \\
\hline
\end{tabular}

Selanjutnya, classifier dibangun kembali menggunakan 93 data latih dan kombinasi parameter terbaik yang telah didapatkan, lalu diuji menggunakan 23 data uji. Rata-rata hasil pengujian dari 10 eksperimen pada masing-masing classifier dan ensemble classifier ditunjukkan pada Tabel 9. Terlihat bahwa secara keseluruhan hasil klasifikasi menggunakan 4 fitur saja lebih 
baik dibandingkan saat menggunakan keseluruhan fitur. Hal ini menunjukkan bahwa 4 fitur tersebut mampu mempermudah classifier untuk menemukan bidang pemisah data dari kelas yang berbeda, sehingga classifier dapat memberikan hasil yang lebih baik. Jika dilihat dari masingmasing classifier nampak bahwa kNN memberikan hasil yang paling rendah dari classifier lainnya, sedangkan ELM dan SVM memberikan hasil yang hampir sama dalam hal akurasi dan G-mean. Akan tetapi, performa ensemble classifier tidak lebih baik dari classifier tunggal ELM maupun SVM dalam hal akurasi, namun nilai G-mean yang didapat sedikit lebih baik dibanding ELM dan SVM.

Perbandingan hasil prediksi saat menggunakan single classifier maupun ensemble classifier pada subsample data uji ke-9 dapat dilihat pada Tabel 10. Terlihat bahwa kNN paling banyak memberikan prediksi yang salah, sedangkan pada SVM dan ELM sebagian besar letak kesalahan prediksi berada pada instance data yang sama (data nomor 3, 4, 7 dan 17), sehingga diversity antara kedua classifier tersebut rendah, akibatnya saat digabungkan tidak mampu menurunkan jumlah kesalahan prediksi.

Tabel 9. Rata-Rata Hasil Pengujian Menggunakan 4 Fitur

\begin{tabular}{crrrr}
\hline Classifier & Akurasi & Sensitivity & Specificity & \multicolumn{1}{c}{ G-mean } \\
\hline ELM & $83.04 \%$ & $82.31 \%$ & $84.00 \%$ & $80.18 \%$ \\
\hline SVM & $82.61 \%$ & $90.00 \%$ & $73.00 \%$ & $80.74 \%$ \\
\hline kNN & $76.52 \%$ & $82.31 \%$ & $69.00 \%$ & $74.54 \%$ \\
\hline Ensemble & $82.17 \%$ & $87.69 \%$ & $75.00 \%$ & $80.85 \%$ \\
\hline
\end{tabular}

Tabel 10. Perbandingan Hasil Prediksi pada Subsample Data Ke-9

\begin{tabular}{ccccccccccccc}
\hline No & ELM & SVM & kNN & Ensemble & Target & No & ELM & SVM & kNN & Ensemble & Target \\
\hline 1 & 0 & 0 & 0 & 0 & 0 & 13 & 1 & 1 & 1 & 1 \\
\hline 2 & 0 & 0 & 1 & 0 & 0 & 14 & 1 & 1 & 1 & 1 \\
\hline 3 & 1 & 1 & 1 & 1 & 0 & 15 & 1 & 1 & 1 & 1 \\
\hline 4 & 1 & 1 & 1 & 1 & 0 & 16 & 1 & 1 & 1 & 1 \\
\hline 5 & 0 & 0 & 0 & 0 & 0 & 17 & 0 & 0 & 0 & 0 \\
\hline 6 & 0 & 0 & 0 & 0 & 0 & 18 & 1 & 1 & 1 & 1 \\
\hline 7 & 1 & 1 & 1 & 1 & 0 & 19 & 1 & 1 & 1 & 1 \\
\hline 8 & 0 & 0 & 0 & 0 & 0 & 20 & 1 & 1 & 1 & 1 \\
\hline 9 & 0 & 0 & 0 & 0 & 0 & 21 & 1 & 1 & 1 & 1 \\
\hline 10 & 1 & 0 & 0 & 0 & 0 & 22 & 1 & 1 & 1 & 1 \\
\hline 11 & 1 & 1 & 1 & 1 & 1 & 23 & 1 & 1 & 1 \\
\hline 12 & 1 & 1 & 1 & 1 & 1 & & & & 1 \\
\hline
\end{tabular}

\section{KESIMPULAN}

Pada penelitian ini telah dilakukan klasifikasi kanker payudara berdasarkan data anthopometric (usia dan BMI/ Body Mass Index) serta data dari hasil tes darah rutin (glucose, insulin, HOMA, leptin, adiponectin, resistin, MCP-1). Penelitian ini membandingkan klasifikasi dengan single classifier (ELM, SVM dan $\mathrm{kNN}$ ) dan klasifikasi dengan ensemble classifier yang menggabungkan ketiga algoritma tersebut dengan penentuan kelas majority voting. Pembagian data dilakukan dengan three way data split. Hasil yang didapat menunjukkan bahwa:

1. Pada saat menggunakan keseluruhan fitur penggunaan ensemble classifier lebih baik daripada single classifier dalam hal akurasi maupun G-mean. Pada skenario ini, single classifier yang digunakan, yaitu ELM, SVM dan kNN memberikan hasil yang hampir sama (berdekatan nilainya).

2. Pada saat menggunakan fitur resistin, glucose, age, dan BMI, kNN memberikan performa yang jauh lebih rendah dibanding single classifier lainnya. Sedangkan penggunaan ensemble classifier sedikit lebih baik dalam hal G-mean, namun sedikit lebih rendah dalam hal akurasi. Hal ini disebabkan classifier yang digunakan sebagian besar memiliki letak kesalahan pada instance data yang sama (diversity antar classifier rendah), sehingga saat digabungkan tidak mampu menurunkan tingkat kesalahan. 
Penelitian selanjutnya dapat mencoba model ensemble method yang lain, seperti bagging dan boosting, serta algoritma seleksi fitur lainnya untuk meningkatkan hasil akurasi.

\section{DAFTAR PUSTAKA}

[1] American Cancer Society, Cancer Facts \& Figures 2019. Atlanta: American Cancer Society, 2019.

[2] Kementerian Kesehatan, "Hari Kanker Sedunia 2019," 2019. [Online]. Available: http://sehatnegeriku.kemkes.go.id/baca/fokus-utama/20190131/2329273/hari-kankersedunia-2019. [Accessed: 21-Jul-2019].

[3] T. R. Golub et al., "Molecular Classification of Cancer: Class Discovery and Class Prediction by Gene Expression Monitoring," vol. 286, no. October, pp. 531-537, 1999.

[4] M. K. Kerr and G. A. Churchill, "Experimental Design for Gene Expression Microarrays," Biostatistics, vol. 2, no. 2, pp. 183-201, 2001.

[5] M. Patrício et al., "Using Resistin, Glucose, Age and BMI to Predict the Presence of Breast Cancer," BMC Cancer, vol. 18(1), no. 29, pp. 1-8, 2018.

[6] R. Zhang, G. Huang, N. Sundararajan, and P. Saratchandran, "Multicategory Classification Using an Extreme Learning Machine for Microarray Gene Expression Cancer Diagnosis," IEEE/ACM Trans. Comput. Biol. Bioinforma., vol. 4, no. 3, pp. 485-495, 2007.

[7] Khadijah, Rismiyati, and A. J. Mantau, "Multiclass Classification of Cancer Based on Microarray Data Using Extreme Learning Machine," in Proceeding of The 1st International Conference on Informatics and Computational Sciences (ICICoS), 2017, pp. 159-164.

[8] S. A. Medjahed, "Breast Cancer Diagnosis by Using k-Nearest Neighbor with Different Distances and Classification Rules," Int. J. Comput. Appl., vol. 62, no. 1, pp. 1-5, 2013.

[9] C. Li et al., "Using the K-Nearest Neighbor Algorithm for the Classification of Lymph Node Metastasis in Gastric Cancer," Comput. Math. Method Med., vol. 2012, pp. 1-11, 2012.

[10] G. Huang, Q. Zhu, and C. Siew, "Extreme Learning Machine: A New Learning Scheme of Feedforward Neural Networks," in Proceeding of International Joint Conference on Neural Networks (IJCNN), 2004, no. July, pp. 985-990.

[11] G.-B. Huang, H. Zhou, X. Ding, and R. Zhang, "Extreme Learning Machine for Regression and Multiclass Classification," IEEE Trans. Syst. Man, Cybern. - Part B Cybern., vol. 42, no. 2, pp. 513-528, 2012.

[12] J. Han and M. Kamber, Data Mining: Concepts and Techniques Second Edition. San Farnsisco: Elsevier Inc., 2006.

[13] Z.-H. Zhou, Ensemble Methods Foundations and Algorithms, Machine Le. Boca raton: CRC Press, 2012.

[14] M. Graña and E. Corchado, "A Survey of Multiple Classifier Systems as Hybrid Systems," Inf. Fusion, vol. 16, pp. 3-17, 2014.

[15] N. Joshi and S. Srivastava, "Improving Classification Accuracy Using Ensemble Learning Technique (Using Different Decision Trees)," Int. J. Comput. Sci. Mob. Comput., vol. 3, no. 5, pp. 727-732, 2014.

[16] G. Brown, J. Wyatt, R. Harris, and X. Yao, "Diversity Creation Methods : A Survey and Categorisation," Hournal Inf. Fusion, vol. 6, no. 1, pp. 1-28, 2005.

[17] G. Huang, "Extreme Learning Machine - Learning Without Iterative Tuning." Tutorial in IJCNN2012/WCCI2012, Brisbane, 2012.

[18] I. K. Timotius and S. G. Miaou, "Arithmetic Means of Accuracies: A Classifier Performance Measurement for Imbalanced Data Set," in International Conference on Audio, Language and Image Processing (ICALIP), 2010, pp. 1244-1251. 


\section{BIOGRAFI PENULIS}

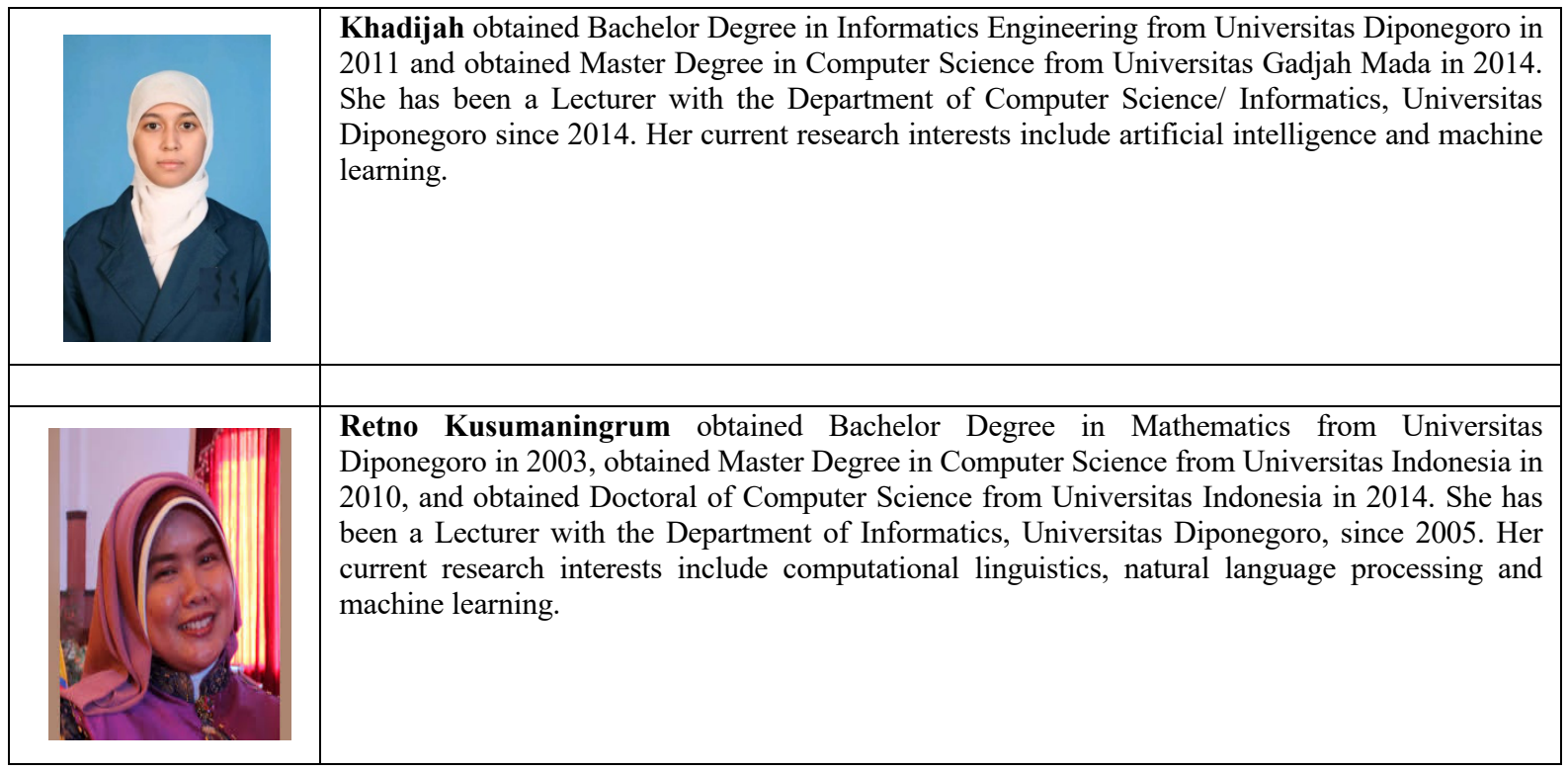

